\title{
Rapid accretion of dissolved organic carbon in the springs of Florida: the most organic-poor natural waters
}

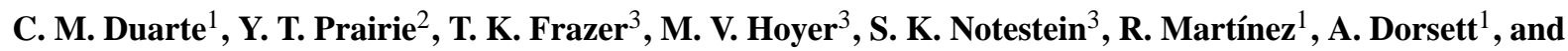 \\ D. E. Canfield ${ }^{3}$ \\ ${ }^{1}$ Global Change Research Department, IMEDEA (CSIC-UIB), Instituto Mediterráneo de Estudios Avanzados, C/Miquel \\ Marqués, 21, 07190 Esporles (Illes Balears) Spain \\ ${ }^{2}$ Département des sciences biologiques, Université du Québec à Montréal, Case postale 8888, succ. Centre-Ville, Montréal, \\ H3C 3P8, Canada \\ ${ }^{3}$ Univ. of Florida, Department of Fisheries and Aquatic Sciences, 7922 NW 71st Street Gainesville, FL 32653-3071, USA
}

Received: 22 June 2010 - Published in Biogeosciences Discuss.: 6 July 2010

Revised: 31 October 2010 - Accepted: 11 November 2010 - Published: 20 December 2010

\begin{abstract}
The concentration of dissolved organic carbon (DOC) in groundwater emanating as spring discharge at several locations in Florida, USA and the net increase in DOC in the downstream receiving waters were measured as part of a larger investigation of carbon dynamics in flowing waters. Springs with high discharge $\left(>2.8 \mathrm{~m}^{3} \mathrm{~s}^{-1}\right)$ were found to be the most organic-poor natural waters yet reported $\left(13 \pm 1.6 \mu \mathrm{mol} \mathrm{CL}^{-1}\right)$, while springs with lesser discharge exhibited somewhat higher DOC concentrations (values ranging from 30 to $77 \mu \mathrm{mol} \mathrm{C} \mathrm{L}{ }^{-1}$ ). DOC concentrations increased rapidly downstream from the point of spring discharge, with the calculated net areal input rate of DOC ranging from 0.04 to $1.64 \mathrm{~mol} \mathrm{C} \mathrm{m}^{-2} \mathrm{~d}^{-1}$ across springs. Rates of DOC increase were generally greater in those springs with high discharge rates. These input rates compare favorably with values reported for gross primary production in these macrophyte-dominated spring systems, assuming that $17 \%$ of macrophyte primary production is lost, on average, as DOC. The measures reported here are possible only because of the remarkably low DOC levels in the up-surging groundwaters and the short residency times of the water in the spring-runs themselves.
\end{abstract}

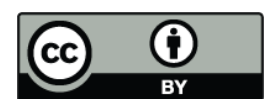

Correspondence to: C. M. Duarte (carlosduarte@imedea.uib-csic.es)

\section{Introduction}

The global pool of dissolved organic carbon (DOC) is substantial (Mulholland, 2003). However, DOC concentrations reported for individual ecosystems can range widely, and some natural waters can be quite depleted in DOC. For example, Sommaruga (2001) reported DOC concentrations as low as $17 \mu \mathrm{mol} \mathrm{C \textrm {L } ^ { - 1 }}$ in ultraoligotrophic alpine lakes, and Arístegui et al. (2002) reported a, average concentration of $42 \mu \mathrm{mol} \mathrm{CL}{ }^{-1}$ in the deep ocean. These are the lowest reported values for fresh and marine waters. However, most aquatic ecosystems have DOC concentrations well in excess of these lower thresholds. Freshwater ecosystems, in particular, tend to exhibit high DOC concentrations, often in excess of $1000 \mu \mathrm{mol} \mathrm{CL}^{-1}$ (Kortelainen 1993, Enache and Prairie 2002).

The high DOC concentration in most natural waters is a rather stable property. In fact, DOC concentrations in most aquatic systems exhibit only modest temporal variability (typically 10\% of the mean, Prairie, unpub. data; Wangersky, 1978; Williams, 1995), although it can show some seasonal variability (e.g. boreal streams, Lepistš et al., 2008). The modest variability in DOC concentrations in relation to most other ecosystems characteristics suggests, at first glance, a slow turnover of this material. However, DOC is certainly a highly dynamic pool, as it is subject to a number of removal processes (e.g., bacterial metabolism, photochemical degradation and flocculation, e.g. del Giorgio and Davis, 2003) and inputs (e.g., atmospheric deposition and autochthonous inputs, especially through the release of dissolved primary

Published by Copernicus Publications on behalf of the European Geosciences Union. 
production from algae and macrophytes; cf. Bertilsson and Jones, 2003). Hence, the relative uniformity of DOC concentrations within a wide variety of aquatic systems noted above must occur as a result of a close balance between inputs and outputs, which, in turn, conceals the dynamic nature of DOC. Further insights into DOC dynamics must therefore be gained through experiments and budget.

Florida contains a large number $(>700)$ of springs, including 33 ranked as first magnitude springs (discharge $>2.8 \mathrm{~m}^{3} \mathrm{~s}^{-1}$ ), and it is arguably the most important regional spring complex worldwide (Scott et al., 2002). Springs serve as the origin of flow for many of Florida's streams and rivers (Scott et al., 2002), in which lush and highly productive ecosystems develop (Odum, 1956, 1958; Duarte and Canfield, 1990a). The groundwaters upwelling at Florida springs are extremely transparent and have been claimed to rank amongst the clearest natural waters (Duarte and Canfield 1990b), thereby suggesting that DOC, which is a major source of light absorption in the UV and blue wavelengths (Kirk, 1983), occurs at very low concentrations. Herein, we provide data that corroborate this suggestion, and we also demonstrate a very rapid increase of DOC in spring runs that can be accounted for by autochthonous sources; submersed aquatic vegetation in particular.

\section{Materials and methods}

\subsection{Sample collection}

We sampled 9 Florida springs spanning a broad range of discharges, from modest to large (range 1.5 to $27.6 \mathrm{~m}^{3} \mathrm{~s}^{-1}$, Table 1). At each spring, divers used acid-washed polycarbonate Nalgene bottles to collect a sample of the upwelling groundwater at the spring boil, i.e. the point of highest discharge. We then collected and additional 2 to 5 water samples (ca. $0.5 \mathrm{~m}$ depth) at stations along the spring run downstream from the initial collection point. Water to be used for DOC analysis was processed immediately, while that used for other chemical analyses (see below) was stored on ice and transported to the laboratory. The distance between the spring boil and downstream sampling stations as well as the mean channel widths were computed from GPS coordinates and digital maps using GIS software (ArcView 3.1).

\subsection{Sample preparation and analyses}

At each sampling station, duplicate water samples for DOC analysis $(10 \mathrm{ml})$ were immediately filtered through a precombusted $\left(450^{\circ} \mathrm{C}\right.$ for a minimum of $\left.4 \mathrm{~h}\right) \mathrm{GF} / \mathrm{F}$ filter and the filtrate transferred to an acid-washed glass ampoule. All samples were preserved with the addition of $100 \mu$ of $2 \mathrm{~N} \mathrm{HCl}$ before flame-sealing the ampoules. DOC analysis was performed using Pt-catalyzed high-temperature combustion on a Shimadzu TOC-5000A analyzer (Qian and Mopper 1996). Distilled UV-radiated water from a Millipore
Simplicity Ultrapure DI water system was used to prepare blanks. Standard curves were prepared with potassium biphthalate (range: 0 to $400 \mu \mathrm{mol} \mathrm{C} \mathrm{L}^{-1}$ ). The instrument blank, ca. $3 \mu \mathrm{mol} \mathrm{CL} \mathrm{L}^{-1}$, was assessed using 2 external standards $(44-45 \mu \mathrm{M}$ and $2 \mu \mathrm{M})$ provided by Dennis A. Hansell and Wenhao Chen (University of Miami) and all reported measurements were appropriately corrected for accuracy. The precision of the measurements, which were derived from the standard curves, was $\pm 1 \mu \mathrm{mol} \mathrm{CL^{-1 }}$. The accuracy and detection limit, derived from the external standards used, was better than $3 \mu \mathrm{mol} \mathrm{C} \mathrm{L}{ }^{-1}$ (average $2.83 \mu \mathrm{mol} \mathrm{C} \mathrm{L}{ }^{-1}$ ). Hence, the analytical techniques and procedures allowed us to accurately estimate DOC in DOC-depleted waters, such as those examined here.

At the laboratory, total phosphorus concentrations were determined using the procedures of Murphy and Riley (1962) with a persulfate digestion (Menzel and Corwin, 1965). Total nitrogen concentrations were determined by oxidizing water samples with persulfate and determining nitrate-nitrogen with second derivative spectroscopy (D'Elia et al., 1977; Simal et al., 1985; Wollin, 1987). Specific conductance $\left(\mu \mathrm{S} \mathrm{cm}^{-1} @ 25^{\circ} \mathrm{C}\right)$ was measured using a Yellow Springs Instrument Model 35 conductance meter. An Accumet model $10 \mathrm{pH}$ meter calibrated with buffers of $\mathrm{pH} 4.0$ and 7.0 was used to measure $\mathrm{pH}$. Total alkalinity $\left(\mathrm{mg} \mathrm{L}^{-1}\right.$ as $\left.\mathrm{CaCO}_{3}\right)$ was determined by titration with $0.02 \mathrm{~N}$ sulfuric acid (Method 2320 B; APHA 1992).

The rate of accretion of DOC along the rivers $\left(\mathrm{DOC}_{\mathrm{acc}} \mu \mathrm{mol} \mathrm{C} \mathrm{m}{ }^{-4}\right.$ ) was calculated as the linear slope of the increase in concentration with distance from the spring origin (boil). Net areal DOC input rates $\left(\mathrm{mol} \mathrm{C} \mathrm{m}^{-2} \mathrm{~d}^{-1}\right)$ along the spring surface were then calculated from the equation:

Net DOC input $=\frac{0.086 \text { Q DOC }}{\mathrm{W} \text { acc }}$

where $\mathrm{Q}$ is the spring discharge $\left(\mathrm{m}^{3} \mathrm{~s}^{-1}\right.$, Table 1$), \mathrm{W}$ is the mean channel width $(\mathrm{m})$ along the length of the spring run and 0.086 is a factor to convert the units to mol $\mathrm{C}$ added per day. These calculations could not be applied to Kings' Bay, the configuration of which is more akin to a lagoon than a river. Estimates of net DOC areal input are conservative as they assume no water inputs along the channel, which does occur in some springs. Increased water inputs either from surface waters or groundwater (as diffuse seepage, for example) would result in an increase in $\mathrm{Q}$, and, as a consequence, an increase in the estimate of the net areal DOC input, and can introduce error in the estimates whenever the DOC concentration in the water inputs varies downstream along the spring. 
Table 1. $\mathrm{pH}$, alkalinity, conductivity, DOC concentration, total $\mathrm{N}$ and total $\mathrm{P}$ concentrations and dissolved oxygen, of the water upwelling at the boils of the Florida springs studied. Water chemistry for Ichetucknee Spring was taken from Scott et al. (2002).

\begin{tabular}{lccccccc}
\hline Spring & $\mathrm{pH}$ & $\begin{array}{c}\text { Total Alkalinity } \\
\mathrm{mg} \mathrm{L}^{-1}\end{array}$ & $\begin{array}{c}\text { Conductivity } \\
\mu \mathrm{mhos}\end{array}$ & $\begin{array}{c}\mathrm{DOC} \\
\mu \mathrm{mol} \mathrm{CL}^{-1}\end{array}$ & $\begin{array}{c}\text { Total P } \\
\mu \mathrm{mol} \mathrm{PL} \mathrm{L}^{-1}\end{array}$ & $\begin{array}{c}\text { Total N } \\
\mu \mathrm{mol} \mathrm{N} \mathrm{L}\end{array}$ & $\begin{array}{c}\mathrm{O}_{2} \\
\mu \mathrm{mol} \mathrm{O}_{2} \mathrm{~L}^{-1}\end{array}$ \\
\hline $\mathrm{mol} \mathrm{CL}^{-1}$
\end{tabular}

\section{Results}

The groundwater emanating as spring discharge ranged broadly in chemical properties (Table 1). For example, conductivity measurements differed by nearly 50 fold among the systems, and nutrient (total $\mathrm{N}$ ) concentrations differed by as much 25 fold (Table 1). This observed variability in water chemistry could be explained largely by differences in spring discharge; conductivity decreased exponentially $\left(R^{2}=0.76, P<0.01\right)$ and total $\mathrm{N}$ concentration increased linearly $\left(R^{2}=0.36, P<0.05\right)$ with increasing discharge. Spring waters, at the point of highest discharge, were undersaturated in oxygen (mean $\pm \mathrm{SE}$, $110 \pm 17 \mu \mathrm{mol} \mathrm{O} \mathrm{O}_{2} \mathrm{~L}^{-1}$ ), and supported relatively high DIC concentrations (mean $\pm \mathrm{SE}, 2410 \pm 226 \mu \mathrm{mol} \mathrm{CL}^{-1}$ ). DOC concentrations in the spring boils were generally low to very low, but also ranged broadly, from exceedingly low values ( $<10 \mu \mathrm{mol} \mathrm{C} \mathrm{L}{ }^{-1}$ in Silver Spring) to moderate concentrations $\left(76.8 \mu \mathrm{mol} \mathrm{C} \mathrm{L}^{-1}\right.$ in Homosassa Spring). DOC concentrations declined with increasing spring discharge (Fig. 1). First magnitude springs, i.e. springs with high $\left(>2.8 \mathrm{~m}^{3} \mathrm{~s}^{-1}\right)$ discharge, maintained very low DOC concentrations (mean $\left.\pm \mathrm{SE}, 13.1 \pm 1.6 \mu \mathrm{mol} \mathrm{C} \mathrm{L}{ }^{-1}\right)$, likely representing that of the Floridian aquifer. These findings render these, to the best of our knowledge, the most organic-depleted natural waters yet examined. DOC concentrations also declined with increasing total nitrogen concentration (Fig. 1).

DOC concentrations increased rapidly downstream from the origin of the springs to reach rather high values at distances of a few kilometers from the spring boil in some springs (Fig. 2). The rates of accretion in DOC ranged broadly from 2.7 to $72.5 \mu \mathrm{mol} \mathrm{C} \mathrm{m}^{-4}$ (Table 2). DOC concentrations tended to increase steadily downstream in all systems, but increased more sharply in some springs (e.g., Silver Springs, Fig. 2, Table 2) than others (e.g., Rainbow Springs, Table 2). The calculated net areal input rate of DOC ranged from 0.04 to $1.64 \mathrm{~mol} \mathrm{C} \mathrm{m}^{-2} \mathrm{~d}^{-1}$ across all sampled springs (Table 2).

\section{Discussion}

The data presented here suggest that there are two groundwater masses contributing to the discharge of the Florida springs: (1) a water mass highly depleted in dissolved organic carbon with high nitrogen concentrations and low conductivity, and (2) a water mass with higher DOC concentrations, higher conductivity and lower total nitrogen concentrations. This is in accord with the presence of two distinct groundwater masses in Florida, a superficial aquifer and the Upper Floridan Aquifer system (Miller, 1986), representing a recent water mass with high DOC and moderate total nitrogen levels and an older (residence time $20 \mathrm{y}$, Scott 2002) water mass depleted in DOC and enriched in total nitrogen, respectively. Typical residence times in the surficial aquifer system range from days to perhaps hundreds of years, whereas residence times in the regional flow system of the Floridan aquifer system in the west-central part of the state, where most springs were sampled here, have been found to exceed 30000 years (Maddox et al., 1992). The low $\mathrm{O}_{2}$ and high DIC concentrations of the spring waters indicate that loss of DOC in both the superficial aquifer and Upper Floridan Aquifer occurs through microbial respiration of the organic matter during the process of groundwater recharge, which likely involves anaerobic pathways. This, in turn, suggests that DOC should be biologically available or semi-available. Moreover, the warm temperature in this aquifer (emerging at about $25^{\circ} \mathrm{C}$ ) enhances respiration rates of prokaryotes, which should contribute to deplete the DOC pool. Microbial respiration over the long residence time of the waters in the Upper Floridan Aquifer system renders these the most organic-depleted waters yet reported in the biosphere.

Indeed, groundwater DOC concentrations are highly variable in across Florida and across the world, with median DOC values ranging between 15 to $200 \mu \mathrm{mol} \mathrm{CL}^{-1}$ (Table 3). The broad range of DOC concentration in Florida springs is not unique, as broad, order-of-magnitude ranges 
Table 2. Water discharge, mean channel width, net rate of DOC increase (mean \pm SE), calculated net input rate of DOC and gross primary production for Florida springs. Salt Springs calculations are based on two points only and have, therefore, no error estimate. Water discharge are the most recent values reported in Scott et al. (2002) and Rosenau et al. (1977). Net primary production from (1) Odum (1957) and (2) Duarte and Canfield (1990a).

\begin{tabular}{lccccccc}
\hline Spring & $\begin{array}{c}\text { Discharge } \\
\mathrm{m}^{3} \mathrm{~s}^{-1}\end{array}$ & $\begin{array}{c}\text { Channel } \\
\text { width }(\mathrm{m})\end{array}$ & $\begin{array}{c}\text { DOC accretion } \\
\mu \mathrm{mol} \mathrm{DOC} \mathrm{m} \mathrm{m}^{-4}\end{array}$ & & $\begin{array}{c}\text { Net DOC input } \\
\mathrm{mol} \mathrm{C} \mathrm{m}^{-2} \mathrm{~d}^{-1}\end{array}$ & $\begin{array}{c}\text { Net Primary Production } \\
\left(\mathrm{mol} \mathrm{C} \mathrm{m}^{-2} \mathrm{~d}^{-1}\right)\end{array}$ \\
\hline Alexander & 2.7 & 42.2 & 54.7 & \pm & 28 & 0.30 & $0.51(2)$ \\
Homosassa & 2.5 & 79.6 & 16.4 & \pm & 5.4 & 0.04 & $7.91(2)$ \\
Ichetucknee & 5.3 & 23.4 & 3.4 & \pm & 0.7 & 0.07 & 0.46 \\
Rainbow & 17.9 & 43.6 & 2.7 & \pm & 3.7 & 0.10 & $1.5(1)-2.66(2)$ \\
Salt & 2.2 & 108.3 & 72.5 & & & 0.13 & $1.35(2)$ \\
Silver & 15.7 & 34.4 & 41.5 & \pm 7.5 & 1.64 & $0.58(2)-1.45(1)$ \\
Weeki Wachee & 4.6 & 19.1 & 4.8 & \pm & \pm .6 & 0.10 & $0.60(2)-0.78(1)$ \\
\hline
\end{tabular}

Table 3. Reported DOC concentrations ( $\mu \mathrm{mol} \mathrm{CL^{-1 }}$, mean, media and range) for groundwater and springs systems.

\begin{tabular}{|c|c|c|c|c|c|c|}
\hline \# & Location & County/State/Country & Mean & Median & Range & Source \\
\hline 1 & Bengal Delta Plain & Bangladesh/India & 270.57 & 212.50 & $100-1183$ & Bhattacharya et al., 2002 \\
\hline 2 & Hermon springs & Isreal-Jordan River Catchment & 123.61 & 95.83 & $67-208$ & Brielmann, 2008 \\
\hline 3 & Golan springs & Isreal-Jordan River Catchment & 100.00 & 95.83 & $83-133$ & Brielmann, 2008 \\
\hline 4 & Upper Rhone River & near Lyon, France, EU & 200.00 & 187.50 & $142-292$ & Chatiq and Gibert, 1993 \\
\hline 5 & Kalispell Valley & NW Montana, US & 100.00 & 87.50 & $75-150$ & Craft et al., 2002 \\
\hline 6 & $\begin{array}{l}\text { Savoy Experimental Watershed/ } \\
\text { Springfield Plateau aquifer }\end{array}$ & NW Arkansas & 175.00 & & & Davis et al., 2005 \\
\hline 7 & Northern Calcareous Alps springs & Austria, EU & 75.00 & & $42-100$ & Farnleitner et al., 2005 \\
\hline 8 & Northern Calcareous Alps springs & Austria, EU & 37.50 & & $33-42$ & Farnleitner et al., 2005 \\
\hline 9 & Apopka Spring, FL & Alachua County, Fl, US & 61.33 & & 233 & $\begin{array}{l}\text { Florida STORET - St. John's River } \\
\text { Water Management District }\end{array}$ \\
\hline 10 & Wacissa River Head-Spring & Jefferson County, Fl, US & 37.50 & & $0-42$ & $\begin{array}{l}\text { Florida STORET - Suwannee River } \\
\text { Water Management District }\end{array}$ \\
\hline 11 & Atlantic Coastal Plain aquifer & Chesapeake Bay, Maryland, US & 125.00 & & $33-475$ & Hakenkamp et al., 1993 \\
\hline 12 & Barstow, California & Barstow, California, US & 213.33 & 183.33 & $25-525$ & Hughes et al., 1974 \\
\hline 13 & Upper Floridan Aquifer springs & Suwannee River Basin, FL, US & 47.92 & 50.00 & $0-75$ & Katz, 1999 \\
\hline 14 & Allequash Creek Watershed & Lake District, N. Wisconsin, US & & & $833-1300$ & Krabbenhoft et al., 1995 \\
\hline 15 & 100 groundwater sources in 27 U.S. states & US & 100.00 & 58.33 & $0-1250$ & Leenheer et al., 1974 \\
\hline 16 & Lincolnshire limestone & Eastern England, UK & & & $1083-2333$ & Malard and Hervant, 1999 \\
\hline 17 & Cape Cod groundwater & Waquoit Bay, Massachussets, US & 192.50 & 33.33 & $33-1948$ & Pabich et al., 2001 \\
\hline 18 & Dorvan-Cleyzieu aquifer & S. Jura Mountains, France, EU & 141.67 & & & Simon, 2000 \\
\hline 19 & Oasis Valley groundwater & Southern Nevada, US & 13.73 & 15.20 & $8-25$ & Thomas et al., 2002 \\
\hline \multirow[t]{2}{*}{20} & Hubelj Spring & Vipava Valley, Slovenia & 49.38 & 38.75 & $18-385$ & Trcek et al., 2006 \\
\hline & Florida Springs & Florida, US & 268.00 & 91.60 & $0-9166$ & $\begin{array}{l}\text { Florida Dept. of Natural } \\
\text { Resources and this study }\end{array}$ \\
\hline
\end{tabular}

in groundwater DOC concentrations have been reported for several other regions (Table 3). Moreover, the very low DOC concentrations reported here for some Florida Springs are also shared by some other groundwater systems, as low $\left(<20 \mu \mathrm{mol} \mathrm{C} \mathrm{L}^{-1}\right)$ values have been also reported for groundwaters in Nevada and Slovenia (Table 3). DOC concentrations in Florida springs vary seasonally typically about four fold along the year (Harrington, D., personal communication, GGWIS Combined Springs Database, Ground Water Protection Section, Fl. Dept. of Env. Protection, September 2010), likely dependent on the balance of contributions between the shallow and Upper Floridan aquifers.
Whereas the downstream receiving waters of some springs such as Rainbow Springs remain DOC-poor at considerable distances from their sources, others such as Silver Springs rapidly accumulate high concentrations of DOC. There are two likely sources for the rapid increase of DOC in the spring runs: (1) net inputs from within the spring ecosystems, presumably derived from the lush and highly productive macrophyte communities and associated epiphytes (Odum 1956, 1958, Duarte and Canfield 1990a), and (2) inputs from the adjacent terrestrial ecosystem, which include in some cases (e.g., Silver Springs), swamps. The upper limit to the autochthonous contribution to DOC inputs is set by 

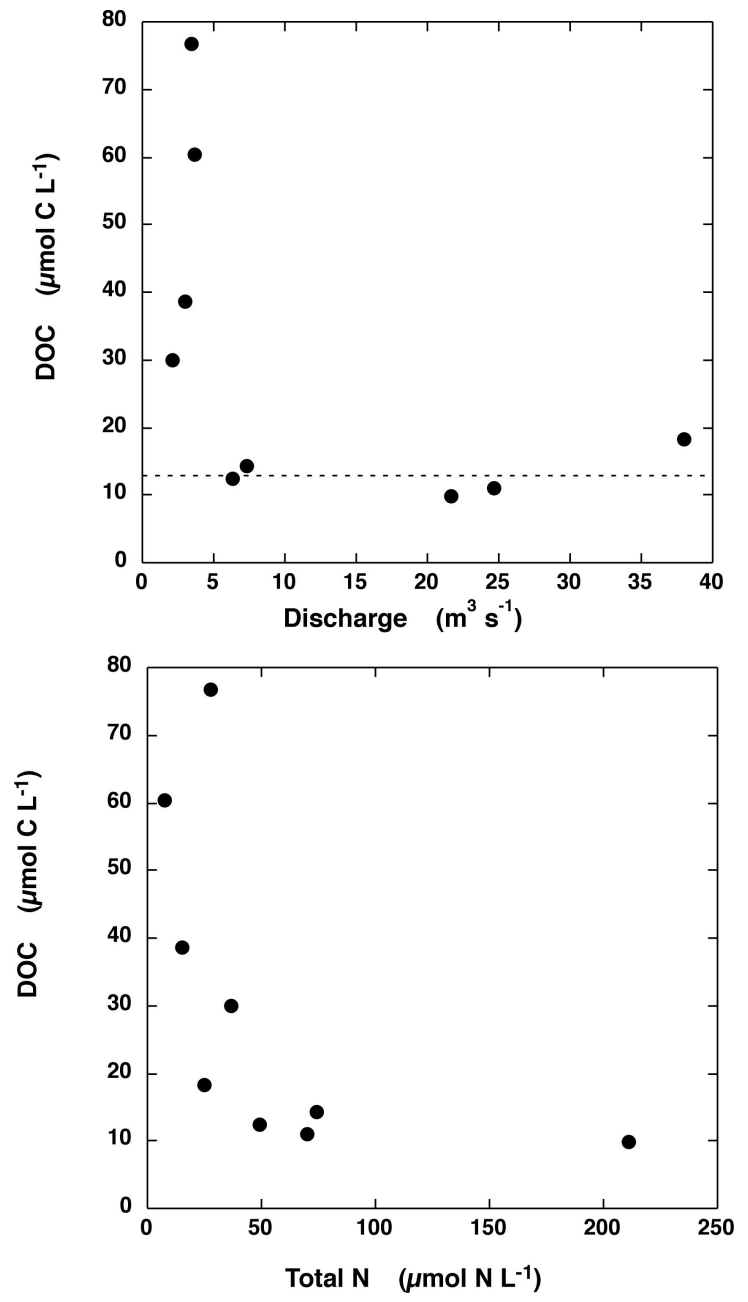

Fig. 1. The relationship between dissolved organic carbon (DOC) concentration and the discharge and total nitrogen concentration in the main discharge (boils) of nine Florida springs. The dotted line shows the mean DOC concentration in springs with discharge $>5 \mathrm{~m}^{3} \mathrm{~s}^{-1}, 13.1 \pm 1.6 \mu \mathrm{mol} \mathrm{C} \mathrm{L}{ }^{-1}$, probably representing the DOC concentration in the Floridan aquifer.

the net community production (NCP) of the spring ecosystems, which has been investigated in the past (Odum 1956, 1958, Duarte and Canfield 1990a). Comparison of the net input rates with previously reported primary production rates for the springs investigated (Table 2, Odum 1958, Duarte and Canfield 1990a) indicate that autochthonous production is sufficient (in all springs except Silver Springs) to account for the calculated rate of net DOC increase, as the median net DOC excretion represents $14 \%$ of primary production (Table 2). This estimate is very crude and should be considered an order-of-magnitude approximation alone, as the primary production values were separated in time from the DOC measurements reported here (Table 2). Nevertheless, the $14 \%$ of primary production required to yield the observed DOC changes is well within the range of reported percent pri-

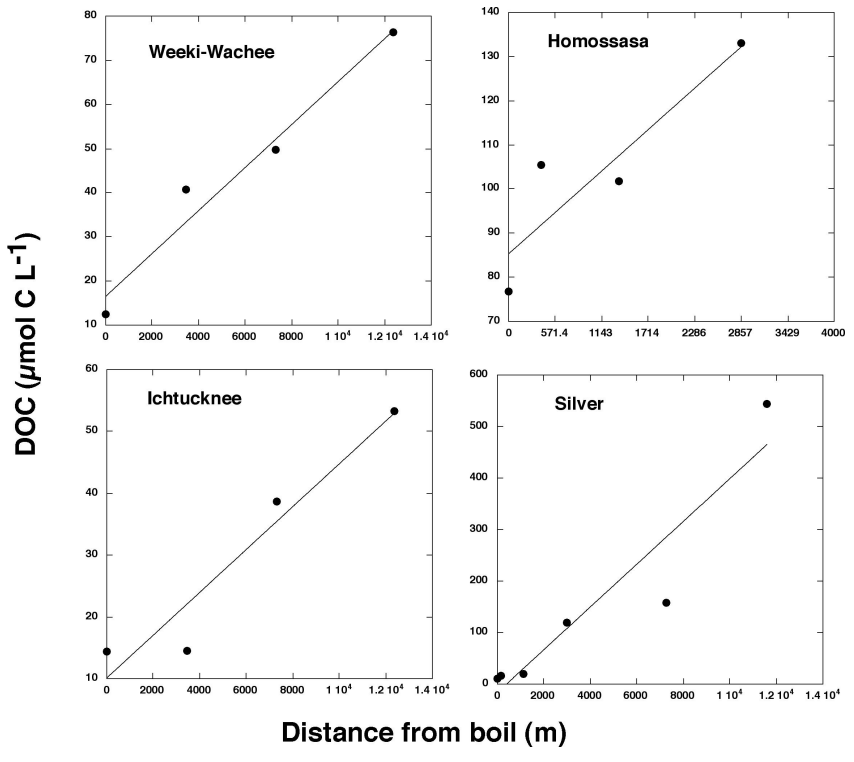

Fig. 2. The relationship between dissolved organic carbon (DOC) concentrations and distance from the point of surgence of groundwater in Weeki Wachee, Homosassa, Ichetucknee, and Silver springs. The solid lines show the fitted least squares regression equations; Weeki Wachee: $\operatorname{DOC}\left(\mu \mathrm{molCL} \mathrm{C}^{-1}\right)=16.5+$ 0.0048 Distance $(\mathrm{m}), R^{2}=0.96$; Homosassa: DOC $\left(\mu \mathrm{mol} \mathrm{C} \mathrm{L}{ }^{-1}\right)$ $=85.3+0.0016$ Distance $(\mathrm{m}), R^{2}=0.81$; Ichetucknee: DOC $\left(\mu \mathrm{mol} \mathrm{CL}{ }^{-1}\right)=10.1+0.0034$ Distance $(\mathrm{m}), R^{2}=0.92 ;$ Silver : DOC $\left(\mu \mathrm{mol} \mathrm{CL} \mathrm{L}^{-1}\right)=15.6+0.041$ Distance $(\mathrm{m}), R^{2}=0.85$.

mary production released as DOC by aquatic macrophytes (Bertilsson and Jones 2003) in all springs except Silver Springs, where net DOC increase exceeds primary production and allochthonous, land-derived DOC inputs must contribute at least half of the net DOC inputs (Table 2). This area is surrounded by swamps that deliver significant amounts of DOC to the spring channel. However, the high primary production of Florida springs, which rank amongst the most productive freshwater ecosystems, is generally attributable to the lush submerged macrophyte communities that they support (Odum 1956, 1958; Duarte and Canfield, 1990a). The lush macrophyte communities of most of Florida's spring-fed streams and rivers render them strongly autotrophic (Odum, 1956), yet the macrophyte communities likely release much of their excess production as dissolved organic carbon.

Because of the remarkably low DOC concentrations in groundwater emanating as spring discharge, Florida springs are ideal systems to study organic carbon dynamics in flowing waters; dynamics which are typically masked in other ecosystems by the natural coupling of input and removal processes. Florida springs are the aquatic ecosystems with the lowest DOC load yet reported. These results show that aquifers with long residence times, such as the Upper Floridan Aquifer, can be highly depleted in DOC, affecting the DOC dynamics of the rivers and streams these groundwaters 
feed. The very low DOC concentration in the groundwater feeding the Florida springs allowed the net DOC input rates to be calculated across significant lengths of the rivers. The remarkably low DOC values of spring waters may provide an opportunity to produce low-DOC reference materials, to be used, similar to available Deep Ocean seawater standards, to test the precision, detection limit and accuracy of DOC measurements in freshwaters, a practice that is lagging behind the use of reference materials for DOC analyses in oceanography. Use of low-DOC, Deep ocean seawater, standards are common practice in marine DOC research, allowing the assessment of the accuracy of results and ensuring the reproducibility of results (Sharp et al., 1995). Producing reference materials requires collecting thousands of replicated samples and a thorough process of certification and verification of DOC concentration in the replicated samples as to determine the allowable margins of error in independent analyses (Sharp et al., 1995). The development of low DOC standards for freshwaters will be a major step forward towards the development of much needed standardized practices for DOC analyses in limnology.

\section{Conclusions}

These results add new and unexpected value to H. T. Odum's statement from nearly half a century ago (Odum, 1958) that the springs of Florida represent a "giant laboratory for the study of natural communities." In addition to the remarkably low DOC levels that rendered measurements of DOC increase rates possible, individual springs in Florida are highly uniform with regard to many of their physical and chemical properties (e.g., temperature, chemistry, discharge) both seasonally and in the long-term (cf. Odum, 1958; Scott, 2002), and approach nearly true steady-state conditions. The results reported for the Florida springs highlight the significant inputs of DOC to aquatic ecosystems from a combination of internal and external sources, which renders DOC the dominant $\mathrm{C}$ pool supporting carbon flux and metabolism in freshwater ecosystems.

Acknowledgements. This research was funded by grants from the Carl S. Swisher Endowment for Water Resources and the Natural Sciences and Engineering Research Council of Canada. We thank Roger Bachmann for sharing his thoughts on an earlier draft of this manuscript. We thank Jason A. Hale as well as the many people associated with the Florida LAKEWATCH program for assistance with field and laboratory work, and C. Barrón, J. C. Alonso and M. Ll. Calleja for assistance with DOC analyses.

Edited by: T. J. Battin

\section{References}

APHA, Standard Methods for the Examination of Water and Wastewater, 18th Edition, American Public Health Association, Washington, D.C., 1992.

Arístegui, J., Duarte, C. M., Agustí, S., Doval, M., ÁlvarezSalgado, X. A., and Hansell, D. A.: Dissolved organic carbon support of respiration in the dark ocean, Science, 298, 1967, 1992.

Bertilsson, S. and Jones Jr, J. B.: Supply of dissolved organic matter to aquatic ecosystems: authocthonous sources, edited by: Findlay, S. E. G. and Sinsabaugh, R. L., Aquatic ecosystems: Interactivity of dissolved organic matter, Academic Press, San Diego, USA., 3-24, 2003.

Bhattacharya, P., Jacks, G., Ahmed, M., Routh, J., and Khan, A. A.: Arsenic in Groundwater of the Bengal Delta Plain Aquifers in Bangladesh, Bull Environ Contam Tox, 69, 538-545, 2002.

Brielmann, Heike, Rostock, Recharge and discharge mechanism and dynamics in the mountainous northern Upper Jordan River Catchment, Isreal, Ph.D. dissertation, Geosciences at LudwigMaximilians-University, Munich, 2008.

Chatiq, M. and Gilbert, J.: Storage and dynamics of organic matter in different springs of small floodplain streams, Hydrobiologia, 251, 199-209, 1993.

Craft, J. A., Stanford, J. A., and Pusch, M.: Microbial respiration within a floodplain aquifer of a large gravel-bed river, Freshwater Biol., 47, 251-261, 2002.

D'Elia, C. F., Steudler, P. A., and Corwin, N.: Determination of total nitrogen in aqueous samples using persulfate digestion, Limnol. Oceanogr., 22, 760-764, 1977.

Davis, R. K., Hamilton, S., and Van Brahana, J.: Escherichia Coli Survival in Mantled Karst Springs and Streams, Northwest Arkansas Ozarks, USA, J. Am. Water Resour. As., 41(6), 12791287, 2005.

del Giorgio, P. A. and Davis, J.: Patterns in dissolved organic matter lability and consumption across aquatic ecosystems, edited by: Findlay, S. E. G., and Sinsabaugh, R. L., Aquatic ecosystems: Interactivity of dissolved organic matter, Academic Press, San Diego, USA, 400-424, 2003.

Duarte, C. M. and Canfield Jr, D. E.: Light absorption in Florida springs, Florida Scientist, 53, 118-122, 1990 b.

Duarte, C. M. and Canfield Jr, D. E.: Macrophyte standing crop and primary production in some Florida spring-runs, Water Resour. Bull., 26, 927-934, 1990a.

Enache, M. and Prairie, Y. T.: WA-PLS diatom-based pH, TP and DOC inference models from 42 lakes in the Abitibi clay belt area (Quebec, Canada), J. Paleolimnol, 27, 151-171, 2002.

Farnleitner, A. H., Wilhartitz, I., Ryzinska, G., Kirschner, A. K. T., Stadler, H., Burtscher, M. M., Hornek, R., Szewzyk, U., Herndl, G., and Mach, R. L.: Bacterial dynamics in spring water of alpine karst aquifers indicates the presence of stable authochthonous microbial endokarst communities, Environ Microbiol., 7(8), 1248-1259, 2005.

Hakenkamp, C. C., Palmer, M. A., and James, B. R.: Metazoans from a sandy aquifer: dynamics across a physically and chemically heterogeneous groundwater system, Hydrobiologia, 287, 195-206, 1994.

Hansell, D. A. and Carlson, C. A.: Net community production of dissolved organic carbon, Global Biogeochem. Cy., 12, 443-453, 1998. 
Hughes, J. L., Eccles, L. A., and Malcolm, R. L.: Dissolved Organic Carbon (DOC), an Index of Organic Contamination in Ground Water Near Barstow, California, Ground Water, 12(5), 283-290, 1974.

Katz, Brian G.: Sources of nitrate in water from springs and the Upper Floridan aquifer, Suwannee River basin, Florida, Impact of Land-Use Change on Nutrient Loads from Diffuse Sources (IUGG 99 Symposium HS3), IAHS Publ. 257, 1999.

Kirk, J. T. O.: Light and photosynthesis in aquatic ecosystems, Cambridge University Press, Cambridge, 1983.

Kortelainen, P.: Content of Total Organic-Carbon in Finnish Lakes and Its Relationship to Catchment Characteristics, Can. J. Fish. Aquat. Sci., 50, 1477-1483, 1993.

Krabbenhoft, D. P., Benoit, J. M., Babiarz, C. L., Hurley, J. P., and Andren, A. W., Mercury cycling in the Allequash Creek watershed, northern Wisconsin, Water Air Soil Poll., 80(1-4), 425433, 1995.

Leenheer, J. A., Malcom, R. L., McKinley, P. W., and Eccles, L. W.: Occurrence of Dissolved Organic Carbon in Selected GroundWater Samples in the United States, J. Res. US Geol. Surv., 2(3), 361-369, 1974.

Lepistš, A., Kortelainen, P., and Mattsson, T.: Increased organic C and $\mathrm{N}$ leaching in a northern boreal river basin in Finland, Global Biogeochem. Cy., 22, GB3029,doi:10.1029/2007GB003175, 2008.

Maddox, G. L., Lloyd, J. M., Scott, T. M., Upchurch, S. B., and Copeland, R.: Florida's Ground Water Quality Monitoring Program Background Hydrogeochemistry, Florida Geological Survey, Tallahassee, Florida, Special Publ., 34, 118 pp., 1992.

Malard, F. and Hervant, F.: Oxygen Supply and the adaptations of animals in groundwater, Freshwater Biol., 41, 1-30, 1999.

Menzel, D. W. and Corwin, N.: The measurement of total phosphorus in seawater based on the liberation of organically bound fractions by persulfate oxidation, Limnol. Oceanogr., 10, 280$282,1965$.

Miller, J. A.: Hydrogeologic framework of the Floridan Aquifer System in Florida and in parts of Georgia, Alabama and South Carolina, U.S. Geological Survey Prof. Paper 1403-B, U.S. Government Printing Office, Washington, 91 p, 1986.

Mulholland, P. J.: Large scale patterns in DOC concentration, flux, and sources, 139-159, edited by: Findlay, S. and Sinsabaugh, R., Aquatic Ecosystems: Interactivity of Dissolved Organic Matter, Elsevier Science, 2003.

Murphy, J. and Riley, J. P.: A modified single solution method for the determination of phosphate in natural waters, Anal. Chim. Ac., 27, 31-36, 1962.
Odum, H. T.: Primary production in flowing waters, Limnol. Oceanogr., 1, 102-117, 1956

Odum, H. T.: Primary production measurements in eleven Florida springs and a marine turtle-grass community, Limnol. Oceanogr. 2, 85-97, 1958.

Pabich, W. J., Valiela, I., and Hemond, H. F.: Relationship between DOC concentration and vadose zone thickness and depth below water table in groundwater of Cape Cod, U.S.A., Biogeochemistry, 55, 247-268, 2001.

Qian, J. and Mopper, K.: Automated high-performance, hightemperature combustion total organic carbon analyzer, Anal. Chem., 68, 3090-3097, 1986.

Scott, T. M., Means, G. H., Means, R. C., and Meegan, R. P.: First magnitude Springs of Florida, Open File Report 85, Florida Geological Survey, Tallahassee, USA, 151 p, 2002.

Sharp, J. H., Benner, R., Bennett, L., Carlson, C. A., Fitzwater, S. E., Peltzer, E. T., and Tupas, L.: Analyses of dissolved organic carbon in seawater: the JGOFS EqPac methods comparison, Mar. Chem., 48, 91-108, 1995.

Simal, J., Lage, M. A., and Iglesias, I.: Second derivative ultraviolet spectroscopy and sulfamic acid method for determination of nitrates in water, J. Anal. Chem., 68, 962-964, 1985.

Kevin Scott, S.: Organic Matter Dynamics and Trophic Structure in Karst Groundwater, Ph.D. dissertation, Virginia Polytechnic Institute and State University, 2000.

Sommaruga, R., The role of solar UV radiation in the ecology of alpine lakes, J. Photoch. Photobio. B, 62, 35-42, 2001.

Thomas, J. M., Benedict Jr, F. C., Rose, T. P., Hershey, R. L., Paces, J. B., and Peterman, Z. E.: Geochemical and Isotopic Interpretations of Groundwater Flow in the Oasis Valley Flow System, Southern Nevada, Nevada Operations Office National Nuclear Security Administration, U.S. Dept. of Energy, 45190, 2002.

Trèek, B, Veseliè, M., and Pezdic, J.: The vulnerability of karst springs - a case study of Hubelj spring (SW Slovenia), Environ. Geol., 49, 865-874, 2006.

Wangersky, P. J.: Production of dissolved organic matter, Mar. Ecol., 4, 115-220, 1978.

Williams, P. J. le B.: Evidence for the seasonal accumulation of carbon-rich dissolved organic material, its scale in comparison with changes in particulate material and the consequential effect on net $\mathrm{C} / \mathrm{N}$ assimilation ratios, Mar. Chem., 51, 17-29, 1995.

Wollin, K. M.: Nitrate determination in surface waters as an example of the application of UV derivative spectrometry to environmental analysis, Acta Hydroch. Hydrob., 15, 459-469, (Ger.), 1987. 